\title{
Closed reduction and fixation of locked symphysis pubis using tubular external fixator: a case report
}

\author{
Tübüler eksternal fiksatör kullanılarak kilitli simfizis pubisin kapalı redüksiyonu ve tespiti: \\ Olgu sunumu
}

\author{
Mehmet Halıcı, M.D., İbrahim Karaman, M.D., İbrahim Halil Kafadar, M.D., Ali Saltuk Argün, M.D. \\ Department of Orthopedics and Traumatology, Medical Faculty of Erciyes University, Kayseri, Turkey
}

\begin{abstract}
Locked symphysis pubis is a kind of pelvic injury in which one pubic bone is jammed in the back of the other or opposite the obturator foramen following lateral compression forces. In this article, we present a 31-year-old female case of locked symphysis pubis which was treated by closed reduction using tubular external fixator. We believe that tubular external fixators are useful devices to perform closed reduction maneuvers for locked pelvic injuries and also help to reduce the need for open reduction and internal implant usage.

Key words: Closed reduction; locked symphysis pubis; tubular external fixator.
\end{abstract}

Pelvic injuries usually occur in young adults as a result of high-energy trauma such as motor vehicle accidents or falling from a height; more rarely they occur in older people with osteoporosis as a result of low-energy trauma such as falling while standing. Sometimes one pubic bone is entrapped behind the other or opposite the obturator foramen. For treatment of this kind of injury closed reduction may be obtained in some cases and plate-screw fixation or external fixation can be used following open reduction when closed reduction cannot be obtained.

We present a case of locked symphysis pubis treated by closed reduction using a tubular fixator and review the literature.

\section{CASE REPORT}

After being evaluated in another hospital due to an out of vehicle traffic accident, a 31-year-old female
Simfiz pubisin kilitlenmesi, yandan gelen sıkıştırıcı kuvvetler sonrasında bir pubik kemiğin diğerinin arkasında ya da karşı obturator foramende takılı kaldığ 1 bir pelvis yaralanması türüdür. Bu makalede 31 yaşında kadın hastada tübüler eksternal fiksatör kullanılarak kapalı redüksiyon ile tedavi edilen bir kilitli simfiz pubis olgusu sunuldu. Tübüler eksternal fiksatörlerin kilitli pelvis yaralanmalarında kapalı redüksiyon manevralarının uygulanmasında yararlı olduğuna ve bu cihazların açık redüksiyon gereksinimini azalttığı gibi, dahili implant kullanma gereksinimini de azaltacağına inanmaktayız.

Anahtar sözcükler: Kapalı redüksiyon; kilitli simfizis pubis; tübüler eksternal fiksatör.

patient was in good general condition with normal consciousness when assessed in the emergency department of our hospital to which she was transferred. There was tenderness on the patient's symphysis pubis and in the lumbosacral region; in addition pelvic compression examination was painful. Neurological examination and the peripheral circulation of the patient were normal. On plain radiographs (Figure 1) and computed tomography (CT) (Figure 2) scans of the patient the left pubis was locked overlapping the superoposterior right pubis and a non-displaced facet joint fracture of the S1 vertebra (Figure 3) was detected. There was no pathology in the patient's abdomen and pelvic organs.

The next day the patient underwent surgery. First, a tubular fixator device with compression bars was placed in both iliac wings under fluoroscopic assistance. The locking situation was corrected by

- Received: January 16, 2013 Accepted: February 28, 2013

- Correspondence: İbrahim Karaman, M.D. Alpaslan Mah., Kızılırmak Cad., Özler Sok., Vakıf-Kınaş Apt., No: 4/18, 38030 Melikgazi, Kayseri, Turkey. Tel: +90 532 - 7183353 Fax: +90352-4377686 e-mail: drikaraman@gmail.com 


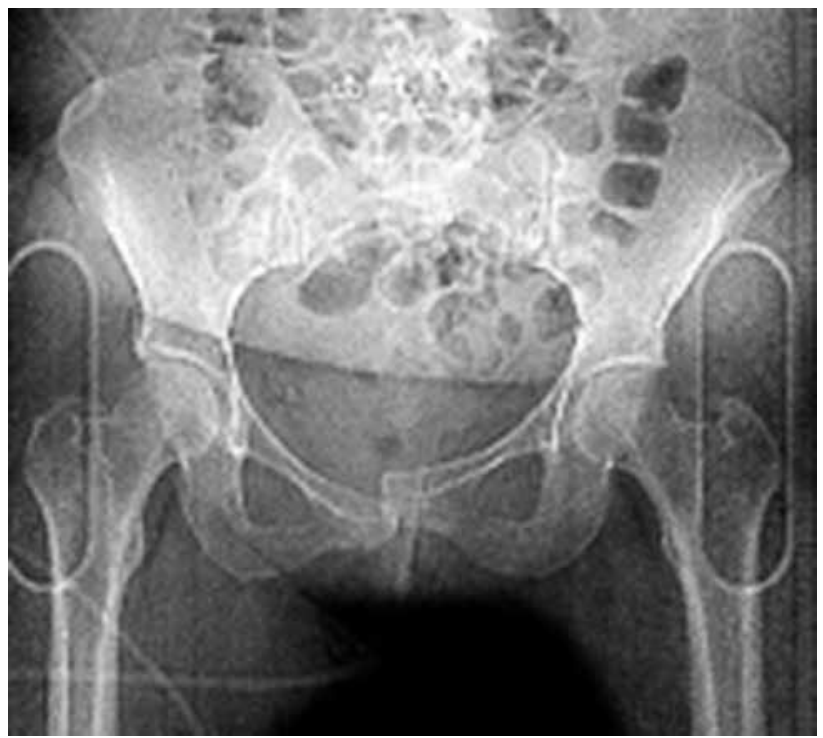

Figure 1. Plain radiogram of the patient with locked symphysis pubis before surgery.

distracting the pubic bones followed by compression to close the symphysis pubis. The device was fixed after control of reduction under fluoroscopy (Figure 4). After six weeks of bed rest and a week of full weight bearing mobilization the patient's tubular fixator device was removed at the end of the seventh week. The next day the patient was mobilized with full weight bearing and then discharged.

\section{DISCUSSION}

Considered hemodynamically stable because of less bleeding when compared with other pelvic fractures, locked symphysis pubis occurs when one pubic bone is jammed in the back of the other or opposite the obturator foramen due to rupture of the ligaments stabilizing the pelvis. ${ }^{[1]}$ The main structure that prevents unlocking is the pubic tubercle..$^{[2-5]}$

Eggers $^{[6]}$ reported that loading gently may reduce a displaced pubic bone while the knee is in flexion of 90 degrees and the hip is in abduction and external rotation. However this maneuver has the risk of causing fracture in the femoral neck. It is reported that reduction may be provided by stabilizing the opposite iliac bone and using the femur as a lever in Figure $4^{[7]}$ or by applying longitudinal traction to the affected lower extremity; $;^{[6,8]}$ by applying lateral compression while pressing directly on the symphysis pubis; ${ }^{[2,4]}$ or by pressing on the symphysis pubis while distracting bilaterally over both iliac crests. ${ }^{[3]}$ Botanlığlu et al. ${ }^{[9]}$ reported that after lateral compression provided by an external fixator placed on both iliac crests, open reduction could be obtained by force applied from the anterior to the posterior with an elevator as a convex surface directed towards the pelvis placed between the pubic bone and opposite the pubic tubercle through the obturator foramen. Open reduction is indicated when closed reduction fails due to strong muscles and ligaments attached to the pelvis. Use of an external fixator is suggested when lateral compression type of pelvic injuries present. Besides their use for definitive surgery it was reported that external fixators can be used temporary for saving life in hemodynamically unstable patients and may help to decrease mortality and morbidity rates to a considerable extent. ${ }^{[10,11]}$

A recent publication reported that superior pubic ramus osteotomy had to be performed to unlock the incarcerated pubic body out of the contralateral obturator foramen and the pubic symphysis had to be fixed with a reconstruction plate due to unstable reduction. ${ }^{[12]}$

To our knowledge 18 similar cases have been reported in the literature. Three of them were managed by closed reduction followed by bed rest. In the remaining cases open reduction was performed to unlock the pelvis. In fourteen of these instrumental maneuvers were used, and suprapubic ramus osteotomy had to be performed in two cases. Platescrew fixation was used in 12 cases, external fixator was used in two cases and double hip spica casting was performed in one case to provide fixation. ${ }^{[9,12]}$

In our case the left pubic bone was jammed behind the pubic tubercle of the right pubic bone and stability
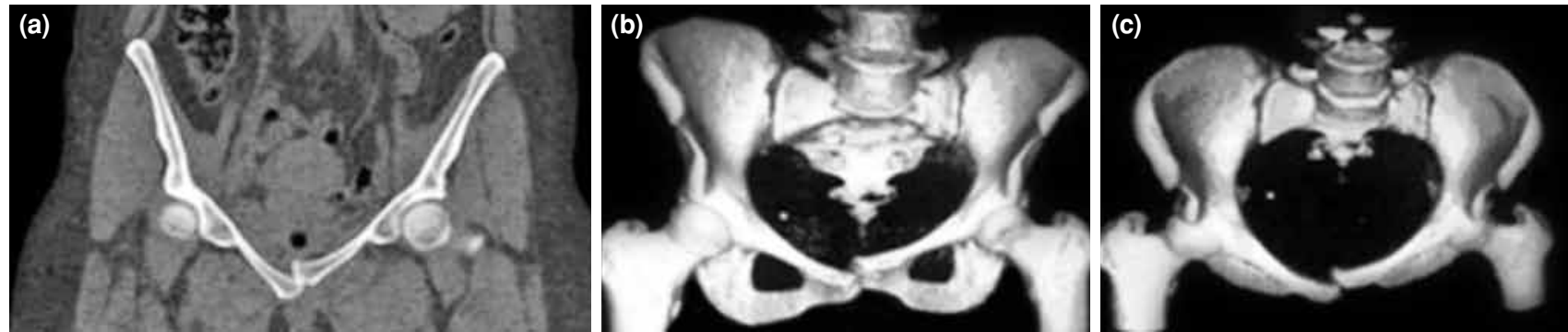

Figure 2. Computed tomography sections of the patients with locked symphysis pubis before surgery. (a) A coronal section of computed tomography, $(\mathbf{b}, \mathbf{c})$ three-dimensional (3D) reconstruction of computed tomography sections. 


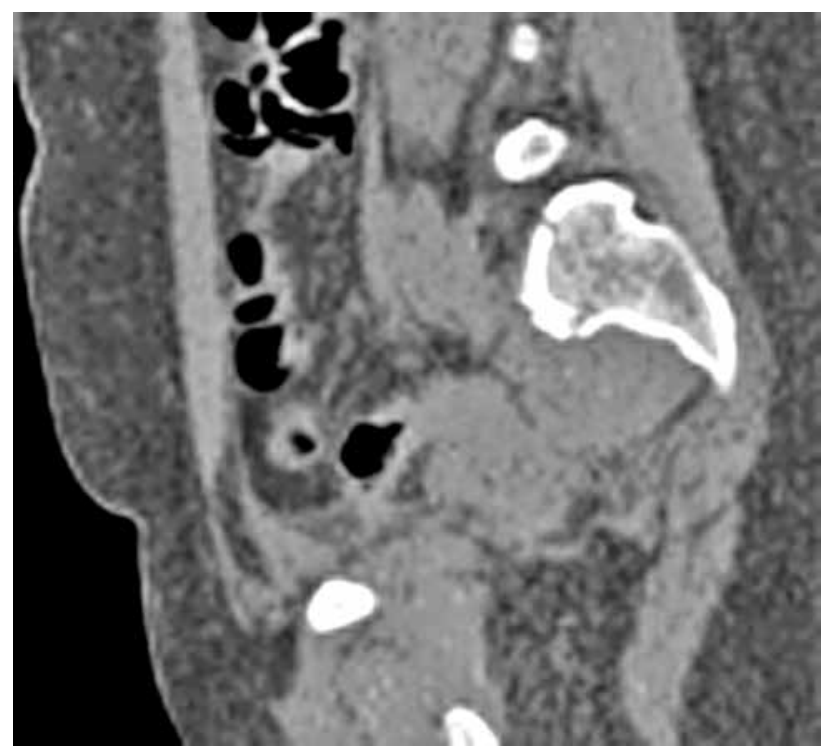

Figure 3. Computed tomography sagittal section of the sacrum fracture.

in the posterior pelvis was relatively preserved because of the intact integrity of the sacroiliac joint and non-displaced sacrum fracture. After distraction using a tubular fixator device, the pubic bones were separated and then compression was applied to close the symphysis pubis, with lateral compression applied at the same time. All these maneuvers were performed closed.

We believe that the application of tubular fixators with compression bars could help in performing reduction maneuvers and provide fixation for the healing of the symphysis pubis as well as minimize the need for internal implant use.

\section{Declaration of conflicting interests}

The authors declared no conflicts of interest with respect to the authorship and/or publication of this article.

\section{Funding}

The authors received no financial support for the research and/or authorship of this article.

\section{REFERENCES}

1. Lunsjo K, Tadros A, Hauggaard A, Blomgren R, Kopke J, Abu-Zidan FM. Associated injuries and not fracture instability predict mortality in pelvic fractures: a prospective study of 100 patients. J Trauma 2007;62:687-91.

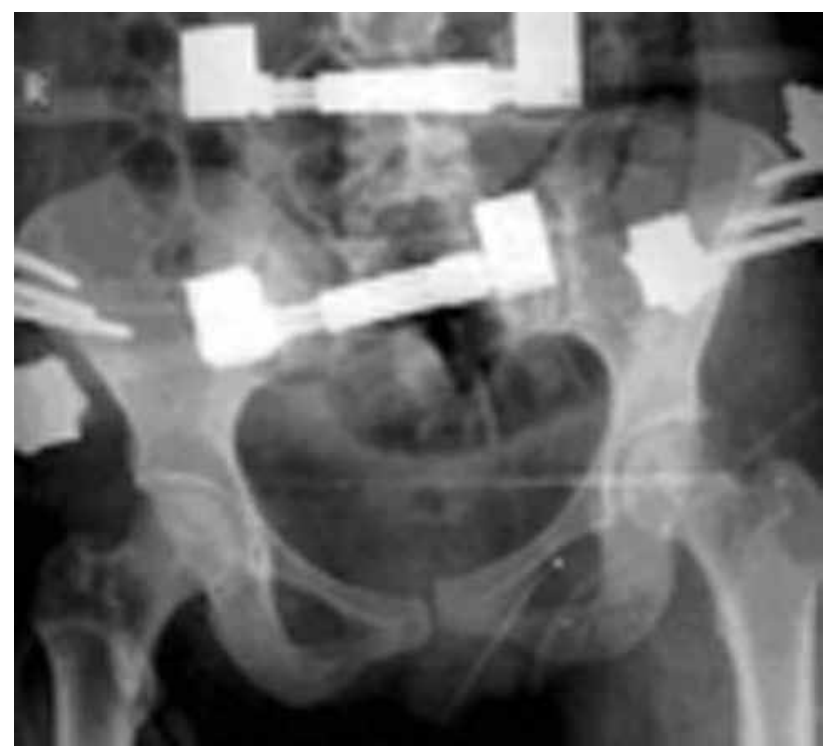

Figure 4. Plain radiogram of the patient with locked symphysis pubis postoperatively.

2. Robinson D, Hendel D, Halperin N. An overlapping pubic dislocation treated by closed reduction: case report and review of the literature. J Trauma 1989;29:883-5.

3. Dorai CR, Kareem BA. Overlapping dislocation of pubic symphysis. Injury 1991;22:329-30.

4. Webb P. Overlapping dislocation of the symphysis pubis: a case report. J Bone Joint Surg [Am] 1977;59:839.

5. Sreesobh KV, Sageer AM, Raffic M. Locked overlapping dislocation of the pubic symphysis into the obturator foramen: a case report. J Orthop Surg (Hong Kong) 2006;14:200-3.

6. Eggers GW. Dislocations of the os coxae. Am J Surg 1952;83:300-7.

7. Cannada LK, Reinert CM. Case report: locked pubic symphysis: an open reduction technique. Clin Orthop Relat Res 2009;467:2192-5. doi: 10.1007/s11999-009-0788-8.

8. Ansari S, Rollins J, Ebraheim NA. Locked pubic symphysis with ipsilateral fracture neck of a femur. J Trauma 2003;54:376-8.

9. Botanlioğlu H, Bilsel N, Kaynak G, Unlü MC. Open reduction technique for overlapping and locked pubic symphysis. Acta Orthop Traumatol Turc 2012;46:77-81.

10. Arazi M, Kutlu A. The role of external fixation for the treatment of the pelvic injuries: indications and current concepts. Eklem Hastalik Cerrahisi 2000;11:104-10.

11. Kapukaya A, Subaşı M, Yıldırım K, Uluç D. Emergency treatment and external fixator applications in pelvic fractures. Eklem Hastalik Cerrahisi 1999;10:54-8.

12. Li KH, Sun BH, Zhu Y, Long HT. Locked pubic symphysis into the obturator foramen: a rare case presentation and literature review. Orthop Traumatol Surg Res 2013;99:10610. doi: 10.1016/j.otsr.2012.08.008. 